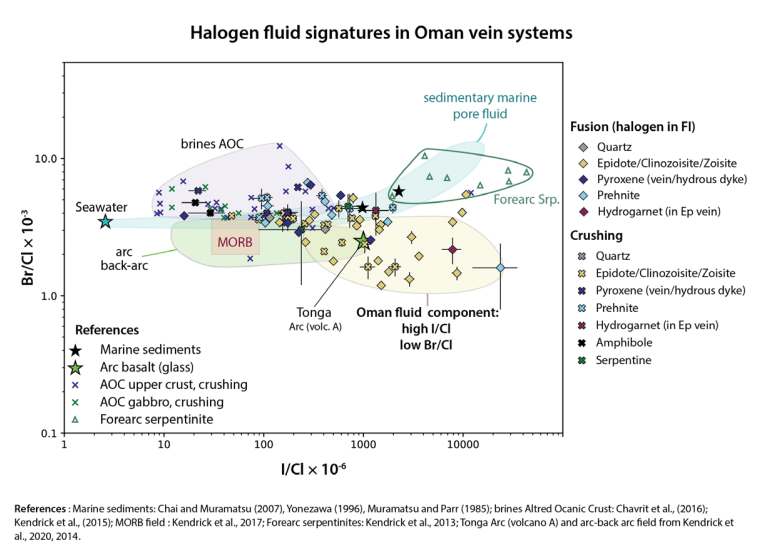

\section{Hydrothermal Circulation and Volatile Distribution in The Oman Ophiolite}

\author{
JOËLLE D'ANDRES ${ }^{1}$, DR. MARK A KENDRICK ${ }^{2}$ AND \\ VICKIE C. BENNETT ${ }^{3}$ \\ ${ }^{1}$ Australian National University \\ ${ }^{2}$ University of Queensland \\ ${ }^{3}$ The Australian National University \\ Presenting Author: joelledandres@gmail.com
}

Noble gases and halogens are key tracers of volatile elements. Concentrated in Earth's surface reservoirs, they are incorporated in the oceanic lithosphere, where they can be used to trace the styles and pathways of hydrothermal alteration and circulation. We studied major vein systems and background alteration along two complete- and intact-transects through fossil oceanic lithosphere preserved in the Oman ophiolite, to determine the mineral sites hosting noble gases and halogens and investigate the timing and setting of hydrothermal alteration.

$\mathrm{Cl}, \mathrm{Br}, \mathrm{I}, \mathrm{Ar}, \mathrm{Kr}$ and $\mathrm{Xe}$ concentrations and noble gas isotope signatures of minerals and rock chips were measured by the noble gas method, using in vacuo crushing and/or fusion based extraction. EPMA, LA-ICP-MS, and SHRIMP were used to further characterize alteration features by investigating the $\mathrm{Cl}$ distribution in mineral phases, the major and trace element content of alteration minerals and the timing of alteration.

The noble gas isotopic signatures of alteration minerals suggest they formed from seawater-derived fluids that reached the crust-mantle boundary. Halogens are incorporated in the mineral structure of amphibole, the main $\mathrm{Cl}$ reservoir in the crustal sections, and serpentine, which can incorporate all three halogens. $\mathrm{Cl}$ concentrations in amphibole vary at the microscale, and serpentine veins are depleted in halogens compared to background serpentinization, suggesting a range of factors influence halogen uptake by these minerals. In the sheeted dyke complex, $\mathrm{Cl}$ and $\mathrm{Br}$ are remobilized from greenschist altered diabase during pervasive chloritization and epidotization, due to the destabilization of amphibole. In the other vein systems (quartz, epidote/clinozoisite/zoisite, prehnite, diopside) halogens are hosted primarily by micro-to nano-fluid inclusions. The halogen composition of the fluid inclusions reflects mixing between a hydrothermal brine component and a second fluid with $\mathrm{I} / \mathrm{Cl}$ of up to $24000 \times 10^{-6}$ ( 7000 times the seawater value), and a $\mathrm{Br} / \mathrm{Cl}$ ratio of $\sim 0.001$. The unique I-rich and $\mathrm{Br}$-poor nature of fluid inclusions, hosted mainly by epidote/clinozoisite veins in the upper crust, is tentatively ascribed a subducted slab-derived origin. Epidote in veins from the lower and upper crust also have different trace element signatures, supporting the interpretation that they formed from different fluids. 